\title{
Temporal trends in abundance and phenology of migratory birds across the Italian Alps during a 20-year period
}

\author{
Alessandro Franzoi ${ }^{1,2 *}$, Simone Tenan ${ }^{1,3}$, Paula Lorenzo Sanchez ${ }^{1}$, \\ Paolo Pedrini ${ }^{1}$
}

\begin{abstract}
Introduction: Bird migration across mountainous regions has been studied usually at single sites due to the difficulty in employing and support a multi-site sampling effort. This may affect inference on migration whose scale is larger that a single site. The Progetto Alpi has been monitoring post-breeding bird migration through the Italian Alps with a network of several ringing stations since 1997. Until 2017, 666,471 ringing data of 191 different species were collected.

Methods: Phenology of bird migration in terms of date of capture and the related elevational distribution during the sampling season (August-November) were analysed for 69 species. For a subset of 45 species the inter-annual variation in phenology along with trends in the number of ringed birds and in the ratio between the number of juveniles and adults ringed, were also analysed.

Results: Migration through the Italian Alps occurred differently between species, with heterogeneity across species in the median date of capture and their elevational distribution. Nolinear trends in phenology were detected. For four species an annual linear increase of the ringed individuals was detected, while for other four species an annual linear decrease of the captures was detected. For two species, an increase of the ratio between the number of the juveniles and the number of adults ringed was detected.

Conclusions: The long-term standardized monitoring of post-breeding migration allowed us to consolidate and increase knowledge of bird migration through Italian southern Alps. The information gathered allowed us to define the temporal and elevation distribution of passerine birds crossing the mountainous area, and to test interannual trends in the number of captures. The main purpose of this work was to report on the information collected in twenty years of field activity, providing a contribution to the understanding this complex phenomenon. Further investigations and more in-depth analyses are necessary to understand how environmental factors and species-specific eco-physiological traits interact and affect migratory strategies of passerine birds in the Italian Alpine region.
\end{abstract}

Keywords: Post-breeding migration, phenology, trends, passerines, Progetto Alpi, standardized ringing stations network.

${ }^{1}$ MUSE - Museo delle Scienze, Sezione Zoologia dei Vertebrati, Corso del Lavoro e della Scienza 3, 38122 Trento, Italia.

2 Area Avifauna Migratrice, Istituto Superiore per la Protezione e la Ricerca Ambientale (ISPRA), Via Cà Fornacetta 9, 40064 Ozzano Emilia (BO), Italia.

${ }^{3}$ National Research Council, Institute of Marine Sciences (CNRISMAR), Arsenale, Tesa 104, Castello 2737/F, 30122 Venezia, Italia.

* Corresponding author: alessandrofranzoi@hotmail.com

(C) 2021 Alessandro Franzoi, Simone Tenan, Paula Lorenzo Sanchez, Paolo Pedrini

Received for publication: 9 April 2021

Accepted for publication: 27 August 2021

Online publication: 23 December 2021
Riassunto - Trend temporali dell'abbondanza e della fenologia di uccelli migratori attraverso le Alpi italiane durante un periodo di 20 anni.

Introduzione: la migrazione degli uccelli attraverso le zone montuose è stata solitamente studiata attraverso dati di singole stazioni di inanellamento a causa delle difficoltà di impiegare e supportare uno sforzo di campionamento in grado di presidiare contemporaneamente più siti. Ciò può influire sulle inferenze riguardo la migrazione la cui scala è maggiore di quella di un singolo sito. Dal 1997 il Progetto Alpi monitora la migrazione post-riproduttiva degli uccelli attraverso le Alpi italiane con una rete di diverse stazioni di inanellamento. Fino al 2017 sono stati raccolti 666.471 dati di inanellamento appartenenti a 191 specie differenti.

Metodi: la fenologia della migrazione degli uccelli, in termini di data di cattura e relativa distribuzione lungo un gradiente altitudinale durante la stagione di campionamento (agosto-novembre), è stata analizzata per 69 specie. Per un sottoinsieme di 45 specie sono state anche analizzate la variazione interannuale della fenologia, insieme all'andamento del numero di uccelli inanellati e del rapporto tra il numero di giovani e il numero di adulti inanellati.

Risultati: la migrazione attraverso le Alpi italiane avviene in modo diversificato tra le specie, con eterogeneità nella data mediana di cattura e nella loro distribuzione lungo il gradiente altitudinale. Non sono state rilevate tendenze lineari significative nella fenologia. Per quattro specie è stato rilevato un aumento lineare annuale degli individui inanellati, mentre per altre quattro specie è stato rilevato un calo lineare annuale delle catture. Per due specie è stato rilevato un aumento del rapporto del numero dei giovani e il numero di adulti inanellati.

Conclusioni: il monitoraggio standardizzato a lungo termine della migrazione post-riproduttiva ha permesso di consolidare e aumentare le conoscenze sulla migrazione degli uccelli attraverso le Alpi italiane. Le informazioni raccolte hanno permesso di definire la distribuzione temporale e di quota degli uccelli che attraversano la catena alpina e di testare l'andamento interannuale del numero di catture. Lo scopo principale di questo lavoro è stato quello di riportare le informazioni raccolte in vent'anni di attività sul campo, fornendo un contributo alla comprensione di questo complesso fenomeno. Saranno necessarie ulteriori indagini e analisi più approfondite per comprendere come fattori ambientali e tratti eco-fisiologici specie-specifici interagiscano e influenzino le strategie migratorie degli uccelli nella Regione alpina italiana.

Parole chiave: migrazione postriproduttiva, fenologia, tendenze, passeriformi, Progetto Alpi, rete di stazioni di inanellamento standardizzate.

\section{INTRODUCTION}

During post-breeding migration, in late summer and autumn, migratory flights in particular of small- and medium-sized passerine birds through the Italian Alps take place at medium and high altitudes along ridges, peaks 
and passes; adverse meteorological conditions, such as westerly winds and fronts, can divert flight directions or interrupt migration when visibility conditions at higher altitudes decreases: in these conditions, migratory birds can be halted and forced to stop over in wetlands, open habitats and forests at lower altitudes, in the valley bottoms or in the Po Plain close to the Alpine foothills (Bruderer \& Winkler, 1976; Bruderer, 1996; Liechti et al., 1995; 1996; Micheli \& Pedrini, 2000; Pedrini et al., 2008; 2012). The analysis of ringing data, collected over long time intervals along migratory flyways, can investigate numerous aspects of bird ecology and their geographic connectivity, such as population trends of migratory birds, the breeding origin of autumnal migrants, spatio-temporal changes in migration phenology and body conditions (Dunn et al., 1997; 2006; Jenni \& Kéry, 2003).

The Progetto Alpi was born in 1997 as a research program proposed by the INFS (Istituto Nazionale della Fauna Selvatica) of Ozzano nell'Emilia (BO), and the Museo Tridentino di Scienze Naturali of Trento (TN), now respectively ISPRA (Istituto Superiore per la Protezione e Ricerca Ambientale) and MUSE (Museo delle Scienze), to improve knowledge about the post-breeding migration of birds through the Italian Alps (Pedrini et al., 2003). The project was based on a network of ringing stations following a standardized field protocol, in order to study migratory patterns of birds crossing the Italian Alps during the post-breeding migration in late summer and autumn (Pedrini et al., 2008). The specific objectives of the project were: 1) to understand the strategies of avoidance/ crossing adopted by migrants confronted with the Alps as an ecological barrier and their ecological and physiological implications; 2) to describe the geographical origin of migrants, based on recoveries and morphometrics; 3 ) to describe the phenology and strategies of migration of the single species; 4) to describe general physiological aspects at the species level; 5) to investigate stopover strategies at the inter and intra-specific level (Pedrini et al., 2008). The results obtained in the first phase of the project (19972002; Pedrini et al., 2008) confirmed the barrier effect of Alps for several species, but also highlighted the presence of an important flyway along the southern part of the chain, that crosses the Italian Alps along a NE-SW axis, as well as along a N-S direction at a lesser extent (Bruderer \& Jenni, 1990; Liechti et al., 1996; Rössler \& Schauer, 2014; Aschwanden et al., 2019), heading towards southern France, the Balearics and Spain, as already described at the beginning of the last century and known as the "Italian-Hispanic route" (Duse, 1930). Subsequently, a report concerning phenology, migratory patterns and trends of several migratory species was produced with data collected between 2001 and 2008 (Pedrini et al., 2012).

The present work reports on the progress of the Progetto Alpi using data updated up to 2017, thanks to the continuous contribution of several ringing stations supported by local Administrations and Parks, research institutions and amateurs. In addition to the list of species and the number of ringed individuals, the observed elevational distribution of captures and the related temporal distribution during the migratory season (August-November) are reported for a subset of species. Finally, for a further subgroup of species, trends in a) phenology (annual average day of capture), b) number of ringed individuals, and c) annual ratio between the number of juveniles and adults captured, were analyzed. The possible phenological shifts and/or changes in the number of ringed individuals that have been observed during the monitoring could be related to various factors (e.g., climatical, meteorological, physiological, ecological) that could act directly or indirectly in the responses to changes in the number and or in the demographic composition of individuals and populations crossing the Alps, but which are obviously extremely difficult to demonstrate and explain; therefore in our study we have no scope to explain which causes determine the observed trends. Hence, the general aim was to propose an analytical approach that would be able to synthesize the data collected by the ringing stations network, with the proposition to stimulate future further investigations.

\section{MATERIALS AND METHODS}

Ringing data were collected at several ringing stations located in the Italian Alpine Region from east to west and from the Po Plain to the innermost mountain areas, collected since 1997 and including updated to 2017 666,471 ringed individuals belonging to 191 species (Pedrini \& Spina, 2021; Pedrini et al., 2021). A synthesis of this dataset, updated to the monitoring season prior to this publication, is available and downloadable on demand the Progetto Alpi website (http://progetto-alpi.muse.it). From the original data set, we selected a sub-sample of stations based on the following criteria: 1) continuous activity of ringing stations for a period of at least one month in the period 1 August - 30 November; 2) availability of 'sampling effort' (i.e. daily netting effort, expressed as the product of mist-net surface in square meters and operational time in hours); 3) captures within eight hours from sunrise, excluding all recaptures of birds ringed in the same ringing station; 4) total sample size of captured individuals $>100$.

\section{Descriptive data}

The observed number of individuals ringed daily divided by sampling effort was reported by considering three elevational ranges for the ringing stations $(0-700$, $701-1400,>1400 \mathrm{~m}$ a.s.1.) and in relation to the season (day of the year). Data collected during the entire sampling season (1 August-30 November) were used. Three age classes were distinguished: adult (EURING age code $\geq 4$ ), juvenile (EURING age code 3 ), unknown age (EURING age code 2) (EURING, 2020). The distribution of captures during season are based on a further selection of the stations on the basis of station-specific ability to capture a particular species (see Tab. 4). For each species, the median dates and related first and third quartile of passage were reported for the total number of captures, adults and juveniles. A general comparison between species wintering in sub-Saharan Africa (hereafter trans-Saharans) and species wintering not further south of the Mediterranean Basin (hereafter intra-Palaearctics) was provided. 


\section{Data analysis}

For a further sub-sample of species belonging to the prior sub-sample of birds ringed in the stations that operated continuously and for at least one consecutive month in each year from 2001 to 2017 (Tab. 1, Fig. 1, Supporting Information 1), the inter-annual variations of the 1) mean date of capture, 2) number of annually ringed individuals, and 3) ratio between the number of juveniles and the number of adults annually ringed, were analyzed. Following and reviewing Pedrini et al. $(2008 ; 2012)$, we considered only data within speciesspecific migration periods (Tab. 2) and also excluded birds ringed with first plumage (EURING code 1), in order to reduce the component of locally-breeding birds in the dataset. Resident (non-migratory) species were considered; for these species and for species that breed in the Alpine region but not in the surroundings of the ringing stations, data of the whole season (August-November) were included. Data were modelled in a Generalized Linear Modelling framework (GLM; McCullagh \& Nelder, 2019) (see below for a detailed model description) and models were compared using the Akaike Information Criterion (AIC; Akaike, 1973) and based our inference on the model with the lowest AIC. In the case of models within two AIC units and if the log-likelihood did not differ substantially between these models, the most parsimonious model, i.e. the model with the lowest number of parameters, was selected (Arnold, 2010).

\section{Inter-annual variation of phenology}

Variation in julian date of capture was modeled for each species in order to test hypotheses on possible variation in phenology during the monitored period (2001-2017). For each species, only ringing stations with a minimum of 8 individuals (a number that we considered a priori sufficient to estimate the average date of passage) per year were considered. Linear and linear mixed effects models were used (link function Gaussian, Zuur et al., 2009), implemented in R (R Development Core Team, 2010), using the packages lmer (Pinheiro et al., 2020) and lme4 (Bates et al., 2015). In particular, the following models were compared:

1) constant (MODP1), i.e., no inter-annual variation of the average date of capture;

2) temporal linear trend (MODP2) of the average date of capture;

3) fixed time (year) effect (MODP3);

4) fixed effect of the ringing station (MODP4), i.e. only a difference in the average date of capture between stations;

5) temporal linear trend additive to the effect of station (MODP5);

6) station-specific temporal linear trend (MODP6), i.e. an inter-annual trend in the average date of capture that varies among station;

7) fixed additive effect of year and station (MODP7);

8) interaction between year and station (MODP8), i.e. year-by-station average capture dates;
9) temporal random variation (MODP9), which includes temporal random effects on the linear predictor for the annual average date of capture;

10) fixed station effect and temporal random variation (MODP10).

In the case of models with temporal random variation, the related temporal random standard deviation (in the scale of the link function, linear in this case) provided a measure of the inter-annual variation in the date of capture not explained by any other variable included in the linear predictor (Kéry, 2010). Model validation was performed following Zuur et al. (2009) by using normalised residuals based on restricted maximum likelihood and plotting them against fitted values and explanatory variables, and assessed normality using histograms of residuals.

\section{Inter-annual trend in the number of ringed birds}

The number of annually ringed individuals in a subset of ringing stations (Passo del Brocon, Bocca di Caset, Passo di Spino, La Passata, Capannelle, Isolino) was modeled to evaluate changes in the abundance of ringed birds during the monitoring period (20012017). The analysis was carried out considering the total number of captures from all the 6 ringing stations considered and cumulating the annual sampling effort of all stations. Generalized linear models with a negative binomial link function and generalized linear mixed models with temporal random effects were used, through the MASS package (Venables \& Ripley, 2002) for R. However, for all species the models with temporal random effects did not converge and results from these models were thus omitted.

The following models were compared:

1) constant (MODT1), i.e., no variation in the number of ringed individuals;

2) effect of sampling effort (MODT2);

3) temporal linear trend (MODT3), which estimates a linear inter-annual trend in the number of individuals ringed;

4) temporal linear trend additive to the effect of sampling effort (MODT4);

5) temporal random variation (MODT5);

6) fixed effect of sampling effort additive to temporal random variation (MODT6).

\section{Inter-annual trend of the ratio between the number of juveniles and adults ringed}

The relationship between the overall number of juveniles and adults ringed annually in 6 ringing stations (Passo del Brocon, Bocca di Caset, Passo di Spino, La Passata, Capannelle, Isolino) was modeled to evaluate the changes in the ratio during the monitored period (2001-2017). The following models were compared:

1) constant (MODR1), i.e., no temporal variation in the ratio;

2) temporal linear trend (MODR2). 


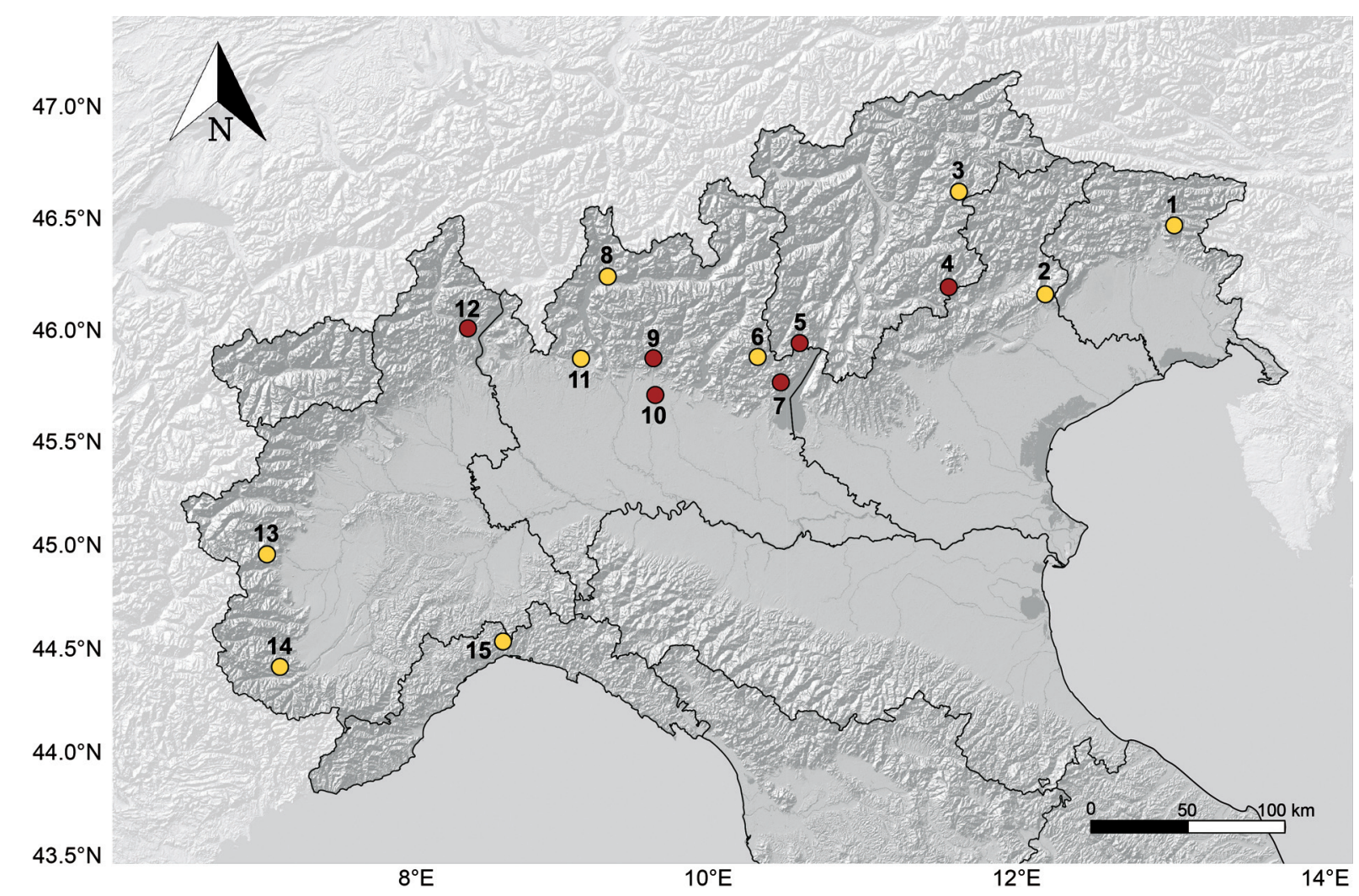

Fig. 1 - Spatial distribution of the ringing stations included for the subsequent analyses (see Tab. 1). Red circles identify ringing stations that operated continuously between 2001 and 2017 for at least yearly one month. / Distribuzione spaziale delle stazioni di inanellamento incluse nelle analisi (vedi Tab. 1). I cerchi rossi indicano le stazioni di inanellamento che hanno lavorato in maniera continuativa tra il 2001 e il 2017 per almeno un mese all'anno.

Tab. 1 - Ringing stations and their respective Municipality and Province, total number of birds ringed, number of species surveyed and years of activity. Numerical superscript is used for the identification of the station. * indicates ringing stations that operated continuously between 2001 and 2017 for at least one month. / Stazioni di inanellamento e loro rispettivi comuni e province, numero totale di catture, numero di specie catturate e anni di attività. Gli apici numerici vengono usati per l'identificazione delle stazioni. * indica le stazioni che hanno operato in maniera continuativa tra il 2001 e il 2017 per almeno un mese.

\begin{tabular}{|c|c|c|c|c|}
\hline Ringing station & Municipality (Province) & $\mathrm{N}$ of bird ringed & N species & Years of activity \\
\hline Malga Confin ${ }^{1}$ & Venzone (UD) & 2,918 & 51 & 2017 \\
\hline Monte Pizzoc² & Fregona (TV) & 14,481 & 77 & $2013-2017$ \\
\hline Passo Gardena ${ }^{3}$ & Selva di Val Gardena (BZ) & 6,515 & 76 & 2013-2017 \\
\hline Passo del Brocon ${ }^{4 *}$ & Cinte Tesino $(\mathrm{TN})$ & 67,664 & 104 & $1997-2017$ \\
\hline Bocca di Caset ${ }^{5 *}$ & Ledro (TN) & 142,740 & 107 & $1997-2017$ \\
\hline Passo della Berga ${ }^{6}$ & Bagolino (BS) & 55,459 & 85 & $1997-2009 ; 2014-2017$ \\
\hline Passo di Spino ${ }^{7 *}$ & Toscolano Maderno (BS) & 61,196 & 108 & $2000-2017$ \\
\hline Poncetta $^{8}$ & Dubino (SO) & 4,261 & 58 & $2015-2017$ \\
\hline La Passata $^{9 *}$ & Miragolo San Marco di Zogno (BG) & 65,124 & 103 & $1997-2017$ \\
\hline Capannelle ${ }^{10 *}$ & Zanica (BG) & 62,443 & 106 & $1999-2017$ \\
\hline Lambrone $^{11}$ & Erba $(\mathrm{CO})$ & 15,298 & 86 & $2014-2017$ \\
\hline Isolino ${ }^{12 *}$ & Verbania (VB) & 63,290 & 113 & $1998 ; 2001-2017$ \\
\hline Colle Vaccera $^{13}$ & Angrogna (TO) & 13,511 & 73 & $2007-2017$ \\
\hline Colle dell'Ortiga ${ }^{14}$ & Demonte $(\mathrm{CN})$ & 4,468 & 64 & $1998-2008$ \\
\hline Passo del Turchino ${ }^{15}$ & Mele (GE) & 3,904 & 50 & $2016-2017$ \\
\hline
\end{tabular}


Tab. 2 - Species-specific presumed starting date of the migratory period. For resident species (Willow Tit and Common Treecreeper) and species which are not breeding in the surroundings of the ringing stations or at all on Italian Alps, the entire monitored period was included. / Data specie-specifica del presunto inizio del periodo migratorio; per le specie residenti (cincia alpestre e rampichino alpestre) e quelle esclusivamente migratrici è stato considerato l'intero periodo di monitoraggio.

\begin{tabular}{|l|c|}
\hline Species & Starting date \\
\hline Great Spotted Woodpecker Dendrocopos major & $8 \mathrm{Sep}$ \\
\hline Tree Pipit Anthus trivialis & $14 \mathrm{Aug}$ \\
\hline Meadow Pipit Anthus pratensis & \\
\hline Water Pipit Anthus spinoletta & $13 \mathrm{Sep}$ \\
\hline Northern Wren Troglodytes troglodytes & $13 \mathrm{Sep}$ \\
\hline Dunnock Prunella modularis & $13 \mathrm{Sep}$ \\
\hline European Robin Erithacus rubecula & $3 \mathrm{Sep}$ \\
\hline Black Redstart Phoenicurus ochruros & $23 \mathrm{Sep}$ \\
\hline Common Redstart Phoenicurus phoenicurus & $14 \mathrm{Aug}$ \\
\hline Whinchat Saxicola rubetra & $14 \mathrm{Aug}$ \\
\hline Eurasian Blackbird Turdus merula & $13 \mathrm{Sep}$ \\
\hline Song Thrush Turdus philomelos & $18 \mathrm{Sep}$ \\
\hline Redwing Turdus iliacus & \\
\hline Mistle Thrush Turdus viscivorus & $23 \mathrm{Sep}$ \\
\hline Cetti's Warbler Cettia cetti & $3 \mathrm{Sep}$ \\
\hline Common Reed-warbler Acrocephalus scirpaceus & $14 \mathrm{Aug}$ \\
\hline Lesser Whitethroat Sylvia curruca & \\
\hline Common Whitethroat Sylvia communis & \\
\hline Garden Warbler Sylvia borin & \\
\hline Eurasian Blackcap Sylvia atricapilla & \\
\hline Common Chiffchaff Phylloscopus collybita & \\
\hline Willow Warbler Phylloscopus trochilus & \\
\hline Goldcrest Regulus regulus & \\
\hline
\end{tabular}

\section{RESULTS}

The selection criteria of the ringing stations allowed to consider the data collected at 15 different sites (Fig. 1). 398,079 individuals of 69 species (4 non-Passerines, 65 Passerines; 22 trans-Saharan migratory species; see Tab. 2) were taken into account for the descriptive analyses of elevational and seasonal phenology, while a smaller proportion of species presented sufficient data for diagnostic analyses of inter-annual trends in phenology, ringing number and age ratio.

\section{Elevational distribution of birds ringed and observed phenology}

Descriptive data which met the proposed criteria (see Materials and Methods) are discussed for 69 species (Tab. 4). All species-specific graphs and images of Descriptive Data and Data Analyses are reported in Pedrini et al., 2021. The observed seasonal pattern of the number of captures showed, as expected, that most of the trans-Saharan migrants passed through the study area in late summer, while intra-Palearctic migrants were more abundant in early autumn (Fig. 2).

\begin{tabular}{|l|c|}
\hline Species & Starting date \\
\hline Common Firecrest Regulus ignicapilla & $3 \mathrm{Sep}$ \\
\hline Spotted Flycatcher Muscicapa striata & \\
\hline European Pied Flycatcher Ficedula hypoleuca & $18 \mathrm{Sep}$ \\
\hline Long-tailed Tit Aegithalos caudatus & \\
\hline Willow Tit Poecile montanus & $29 \mathrm{Aug}$ \\
\hline Coal Tit Periparus ater & $23 \mathrm{Sep}$ \\
\hline Eurasian Blue Tit Cyanistes caeruleaus & $23 \mathrm{Sep}$ \\
\hline Great Tit Parus major & \\
\hline Eurasian Treecreeper Certhia familiaris & $23 \mathrm{Sep}$ \\
\hline Red-backed Shrike Lanius collurio & \\
\hline Common Chaffinch Fringilla coelebs & $13 \mathrm{Sep}$ \\
\hline Brambling Fringilla montifringilla & $18 \mathrm{Sep}$ \\
\hline European Serin Serinus serinus & $18 \mathrm{Sep}$ \\
\hline European Greenfinch Chloris chloris & $28 \mathrm{Sep}$ \\
\hline European Goldfinch Carduelis carduelis & $23 \mathrm{Sep}$ \\
\hline Eurasian Siskin Spinus spinus & \\
\hline Common Linnet Linaria cannabina & \\
\hline Red Crossbill Loxia curvirostra & \\
\hline Eurasian Bullfinch Pyrrhula pyrrhula & \\
\hline Hawfinch Coccothraustes coccothraustes & \\
\hline Rock Bunting Emberiza cia & \\
\hline Reed Bunting Emberiza schoeniclus & \\
\hline
\end{tabular}

The observed number of ringed birds was distributed differently according to their migratory strategies and the age class along the three elevational categories (Fig. 3): in Table 3 we reported for each species their specific elevational index, obtained by dividing the number of individuals captured at each elevational level per the cumulative daily netting effort of the ringing stations. Generally, in the first eight hours after dawn, the majority of birds were captured at higher elevation $(>1400 \mathrm{~m}$ a.s.l.), consisting in 193,124 individuals of 58 species. At medium elevation (between 701 and $1400 \mathrm{~m}$ a.s.1.) 94,555 individuals of 56 species were ringed, and at lower elevation ( $<700 \mathrm{~m}$ a.s.l.) 90,179 individuals of 64 species were ringed. The medium juvenile/adult ratio at the three elevational categories showed a higher proportion of juveniles at the lower altitude. Captures at medium and higher altitudes were represented mainly by gregarious species that migrate in conspicuous flocks during the day, such as finches and tits (e.g., Coal Tit, Common Chaffinch, Brambling) and concentrate at mountain passes. At lower altitudes, and especially in the valley bottoms and in the Po Plain stations, captures were mostly represented by nocturnal trans-Saharan migrants, such as warblers and chats (e.g., Whinchat, Common Reed- 


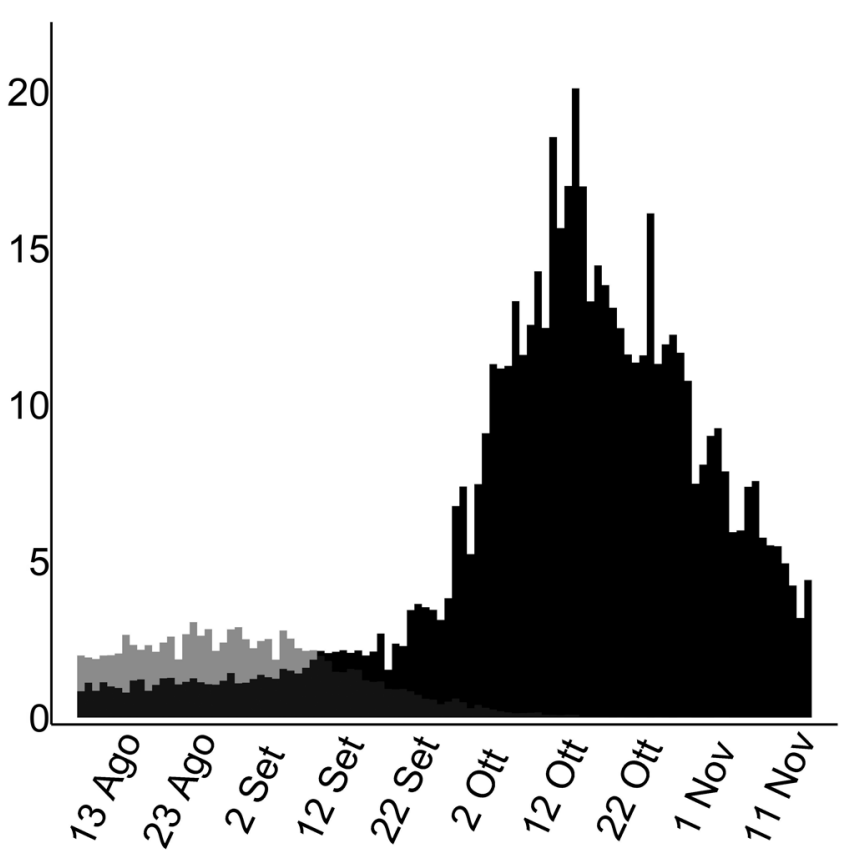

Fig. 2 - Observed seasonal pattern of the daily number of captures (2001-2017) divided the sampling effort (squared meters of mist-nets), showing trans-Saharan (light gray) and intra-Palearctic (dark gray) migrants (see Tab. 3). / Andamento stagionale (2001-2017) del numero giornaliero di catture diviso lo sforzo di campionamento (metri quadri di reti), illutrato per migratori transahariani (grigio chiaro) e intrapaleartici (grigio scuro) (vedi Tab. 3).

warbler, Garden Warbler), that preferably pass and stopover in wetlands or in open and ecotone habitats. Several species were quite common and uniformly ringed along the elevational gradient (e.g., European Robin, Common Restart, Blackcap, Wood Warbler, Common Chiffchaff, Willow Warbler, Pied Flycatcher). Furthermore, some species seemed to be less frequent at medium altitudes (e.g., Tree Pipit, Winter Wren, Eurasian Blackbird, Lesser Whitethroat). Finally, several species were present in just one of the elevational ranges (e.g., the Spotted Nutcracker at lower altitudes or the Penduline-tit at higher altitudes were absent).

Juveniles and adults might differ in the median day of capture, suggesting an anticipation for adults. In some cases, e.g., irruptive species (e.g., Coal Tit) or partially resident species (e.g., European Greenfinch), median day of capture of juveniles could be anticipated.

Elevational and phenological distributions of ringings were graphically reported for every species in their specific panel, reported in Pedrini et al. (2021).

\section{Interannual variation of phenology}

The inter-annual variation of phenology was tested in 23 species (Tab. 5, Supporting Information 2): six transSaharan migrants, 17 intra-Palearctic migrants. For all of them, the MODP8 model was selected as the best model, supporting temporal and station-specific variation in the estimated average date. No temporal trend in the date of capture was supported for any species. No significant differences emerged between estimated mean dates of cap-
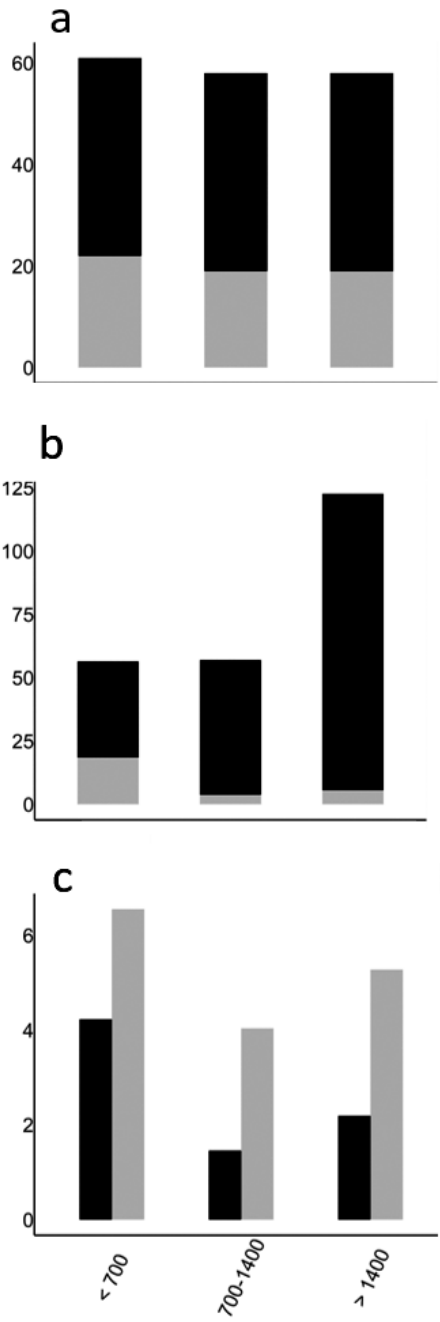

Fig. 3 - Observed elevational distribution of a) the detected number of species, b) the number of captures (2001-2017) divided the sampling effort (squared meters of mist-nets), c) the ratio between number of juveniles and number of adults ringed, showing trans-Saharan (light gray) and intra-Palearctic (dark gray) migrants (see Tab. 3). / Distribuzione altitudinale osservata di a) numero di specie rilevate, b) numero di catture diviso lo sforzo di campionamento (metri quadri di reti), c) rapporto tra numero di giovani e adulti inanellati, illutrato per migratori transahariani (in grigio chiaro) e intrapaleartici (in grigio scuro) (vedi Tab. 3).

ture station at different elevational range. However, visual trends (see Pedrini et al., 2021) suggested that generally the migratory passage is anticipated at higher altitudes.

\section{Inter-annual trend in the number of birds ringed}

The inter-annual trend in the number of birds ringed was analyzed for 45 species (Tab. 6, Supporting Information 3). Abundance of Blackbird, Song Thrush, Firecrest and Long-tailed Tit increased over the sampling period, while abundance of Whinchat, Common Reed-warbler, Willow Warbler and Red-backed Shrike decreased; for Red-backed Shrike, the selected model included also capture effort. Of the remaining 37 species, there was no trend over the years in the number of ringings. Finally, for 13 out of 45 species, the model that takes into account the capture effort was selected. 
Tab. 3 - Number of ringed individuals, elevational capture index (number of ringings/mist-net surface) and age ratio for each elevational range (numbers indicate the ringing stations considered for each elevational range; see Tab. 1). / Numero di individui inanellati, indice altimetrico (numero di inanellamenti/sforzo di cattura) e rapporto di età (giovani vs vadulti) per ogni fascia altimetrica (i numeri indicano le stazioni considerate per ogni categoria; vedi Tab.1).

* Species trans-Saharan migrants. / Specie migratrici transahariane.

\begin{tabular}{|c|c|c|c|c|c|c|c|c|c|}
\hline \multirow[t]{2}{*}{ Species } & \multicolumn{3}{|c|}{$\underset{8,10,11,12,15}{<700 \text { m a.s.l. }}$} & \multicolumn{3}{|c|}{$\begin{array}{c}700-1400 \mathrm{~m} \\
1,7,9\end{array}$} & \multicolumn{3}{|c|}{$\begin{array}{c}>1400 \text { m a.s.l. } \\
2,3,4,5,6,9,10,13\end{array}$} \\
\hline & $\mathbf{N}$ & $\begin{array}{c}\text { Elev. } \\
\text { Index }\end{array}$ & $\begin{array}{l}\text { Age } \\
\text { ratio }\end{array}$ & $\mathbf{N}$ & $\begin{array}{c}\text { Elev. } \\
\text { Index }\end{array}$ & $\begin{array}{c}\text { Age } \\
\text { ratio }\end{array}$ & $\mathbf{N}$ & $\begin{array}{c}\text { Elev. } \\
\text { Index }\end{array}$ & $\begin{array}{l}\text { Age } \\
\text { ratio }\end{array}$ \\
\hline Eurasian Sparrowhawk Accipiter nisus & 66 & 0.04 & 3.85 & 79 & 0.05 & 1.34 & 182 & 0.11 & 1.17 \\
\hline Common Kingfisher Alcedo atthis & 354 & 0.21 & 48.71 & 1 & 0.00 & & & & \\
\hline Great Spotted Woodpecker Dendrocopos major & 170 & 0.10 & 3.45 & 90 & 0.05 & 8.67 & 155 & 0.09 & 3.14 \\
\hline Tree Pipit* Anthus trivialis & 449 & 0.27 & 5.07 & 245 & 0.15 & 2.56 & 574 & 0.33 & 4.74 \\
\hline Meadow Pipit Anthus pratensis & 31 & 0.02 & 3.00 & 89 & 0.05 & 1.87 & 1,057 & 0.61 & 3.07 \\
\hline Northern Wren Troglodytes troglodytes & 1,521 & 0.91 & 5.27 & 578 & 0.35 & 4.19 & 1,212 & 0.70 & 5.37 \\
\hline Dunnock Prunella modularis & 1,935 & 1.15 & 3.66 & 213 & 0.13 & 4.53 & 1,843 & 1.07 & 5.05 \\
\hline European Robin Erithacus rubecula & 15,307 & 9.12 & 5.96 & 4,951 & 2.99 & 6.74 & 27,125 & 15.69 & 5.16 \\
\hline Common Nightingale* Luscinia megarhynchos & 790 & 0.47 & 7.94 & 7 & 0.00 & & 3 & 0.00 & \\
\hline Bluethroat Luscinia svecica & 185 & 0.11 & 4.94 & 4 & 0.00 & & 5 & 0.00 & \\
\hline Black Redstart Phoenicurus ochruros & 53 & 0.03 & 5.00 & 384 & 0.23 & 3.59 & 2,490 & 1.44 & 5.09 \\
\hline Common Redstart* Phoenicurus phoenicurus & 2,001 & 1.19 & 8.60 & 452 & 0.27 & 5.73 & 875 & 0.51 & 6.84 \\
\hline Fieldfare Turdus pilaris & 5 & 0.00 & 1.50 & 64 & 0.04 & 1.00 & 53 & 0.03 & 0.89 \\
\hline Song Thrush Turdus philomelos & 2,099 & 1.25 & 8.41 & 1,236 & 0.75 & 6.29 & 4,572 & 2.64 & 8.06 \\
\hline Redwing Turdus iliacus & 49 & 0.03 & 3.90 & 144 & 0.09 & 3.83 & 183 & 0.11 & 2.60 \\
\hline Mistle Thrush Turdus viscivorus & 6 & 0.00 & 2.00 & 120 & 0.07 & 5.88 & 663 & 0.38 & 5.55 \\
\hline Cetti’s Warbler Cettia cetti & 808 & 0.48 & 9.47 & & & & & & \\
\hline Common Grasshopper-warbler* Locustella naevia & 240 & 0.14 & 6.71 & 56 & 0.03 & 2.40 & 24 & 0.01 & 6.67 \\
\hline Sedge Warbler* Acrocephalus schoenobaenus & 285 & 0.17 & 15.76 & 1 & 1.00 & & & & \\
\hline Marsh Warbler* Acrocephalus palustris & 123 & 0.07 & 12.67 & & & & & & \\
\hline Common Reed-warbler* Acrocephalus scirpaceus & 1,171 & 0.70 & 0.30 & & & & 3 & 0.00 & \\
\hline Icterine Warbler* Hippolais icterina & 214 & 0.13 & 10.56 & 17 & 0.01 & & 11 & 0.01 & 10.00 \\
\hline Melodious Warbler* Hippolais polyglotta & 194 & 0.12 & 37.20 & & & & & & \\
\hline
\end{tabular}




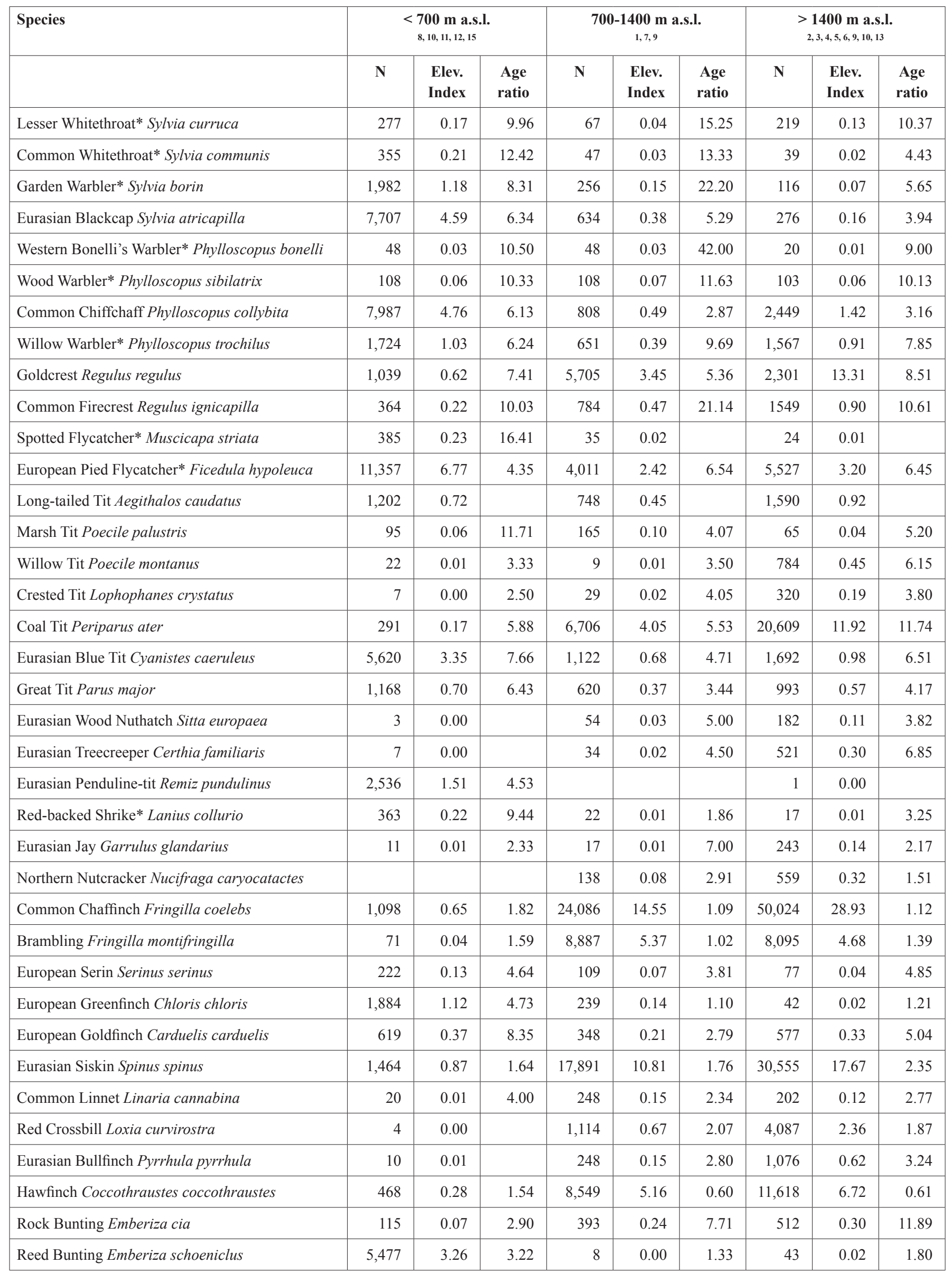


Tab. 4 - Number of ringed individuals, overall, adults and juveniles median days of ringing, days between which the $50 \%$ of individuals are ringed $\left(1^{\text {st }}-3^{\text {rd }}\right.$ Quartiles $)$; ringing stations included are reported for each species (see Tab. 1). / Numero di individui inanellati, data mediana di passaggio totale e suddivisa per giovani e adulti, giorni entro i quali vengono effettuate il $50 \%$ delle catture $\left(1^{\circ}-3^{\circ}\right.$ quartili); codice della stazioni utilizzata nelle analisi (vedi Tab.1).

\begin{tabular}{|c|c|c|c|c|c|c|}
\hline Species & $\mathbf{N}$ & Total & Adults & Juv.s & $\begin{array}{c}1^{\text {st }}-3^{\text {rd }} \\
\text { Quartiles }\end{array}$ & Ringing stations \\
\hline Eurasian Sparrowhawk Accipiter nisus & 316 & $5-O c t$ & 5 -Oct & $6-\mathrm{Oct}$ & 13-Sep - 18-Oct & $2,4,5,6,7,9,10,13,15$ \\
\hline Common Kingfisher Alcedo atthis & 354 & 12-Sep & $4-O c t$ & 11-Sep & 30-Aug - 30-Sep & $8,10,11,12$ \\
\hline Eurasian Wryneck Jynx torquilla & 286 & 28-Aug & 29-Aug & 28-Aug & 20-Aug - 08-Sep & $5,9,10,11,12$ \\
\hline Tree Pipit Anthus trivialis & 1,259 & 6-Sep & 8-Sep & 5-Sep & 30-Aug - 15-Sep & $2,3,4,5,6,7,8,9,10,12,15$ \\
\hline Meadow Pipit Anthus pratensis & 1,153 & $16-O c t$ & 17-Oct & 15 -Oct & 12-Oct - 22-Oct & $1,2,4,5,7,15$ \\
\hline Water Pipit Anthus spinoletta & 1,156 & $5-O c t$ & $4-O c t$ & 5 -Oct & 30-Sep - 09-Oct & $1,2,3,4,11$ \\
\hline Northern Wren Troglodytes troglodytes & 3,261 & 17-Oct & $20-$ Oct & $16-O c t$ & 7-Oct - 25-Oct & $1,2,3,4,5,6,7,8,9,10,11,12,13$ \\
\hline Dunnock Prunella modularis & 3,907 & $11-$ Oct & $14-O c t$ & $10-$ Oct & 3 -Oct - 20-Oct & All except 7 \\
\hline European Robin Erithacus rubecula & 47,383 & 9-Oct & $12-O c t$ & $8-O c t$ & 30-Sep - 16-Oct & All \\
\hline Common Nightingale Luscinia megarhynchos & 789 & 21-Aug & 21-Aug & 21-Aug & 13-Aug - 30-Aug & $10,11,12$ \\
\hline Bluethroat Luscinia svecica & 185 & 10-Sep & 10-Sep & 11-Sep & 30-Aug - 20-Sep & $8,11,12$ \\
\hline Black Redstart Phoenicurus ochruros & 2,863 & 18-Oct & 21-Oct & 18-Oct & 12-Oct - 23-Oct & $1,2,3,4,5,6,7,13,15$ \\
\hline Common Redstart Phoenicurus phoenicurus & 3,277 & 11-Sep & 13-Sep & 11-Sep & 25-Aug - 26-Sep & $1,3,4,5,6,7,8,9,10,11,12$ \\
\hline Eurasian Blackbird Turdus merula & 3,863 & $16-O c t$ & 19-Oct & 15 -Oct & 5 -Oct - 25-Oct & All \\
\hline Fieldfare Turdus pilaris & 94 & 8-Nov & 6-Nov & 10-Nov & 1-Nov - 17-Nov & $2,3,7,9$ \\
\hline Song Thrush Turdus philomelos & 7,907 & 12-Oct & $12-$-Oct & 12-Oct & 4-Oct - 18-Oct & All \\
\hline Redwing Turdus iliacus & 396 & 29-Oct & 27-Oct & 30 -Oct & 25-Oct - 1-Nov & $1,2,4,5,6,7,9,10,13,15$ \\
\hline Mistle Thrush Turdus viscivorus & 756 & 14-Oct & 14-Oct & 14-Oct & 7-Oct - 21-Oct & $1,2,4,5,6,7,13$ \\
\hline Cetti's Warbler Cettia cetti & 808 & 13-Sep & 17-Sep & 9-Sep & 27-Aug - 3-Oct & $8,10,11,12$ \\
\hline Common Grasshopper-warbler Locustella naevia & 269 & 10-Sep & 3-Sep & 11-Sep & 29-Aug - 22-Sep & $1,3,8,9,11,12$ \\
\hline Sedge Warbler Acroephalus. schoenobaenus & 280 & 4-Sep & 19-Aug & 6-Sep & 19-Aug - 15-Sep & 11,12 \\
\hline Marsh Warbler Acrocephalus palustris & 116 & 16-Aug & 9-Aug & 18-Aug & 8-Aug - 24-Aug & 12 \\
\hline Eurasian Reed-warbler Acroephalus. scirpaceus & 9,023 & 2-Sep & 14-Aug & 4-Sep & 17-Aug - 18-Sep & $8,11,12$ \\
\hline Icterine Warbler Hippolais icterina & 214 & 3-Sep & 17-Aug & 3-Sep & 24-Aug - 9-Sep & $10,11,12$ \\
\hline
\end{tabular}




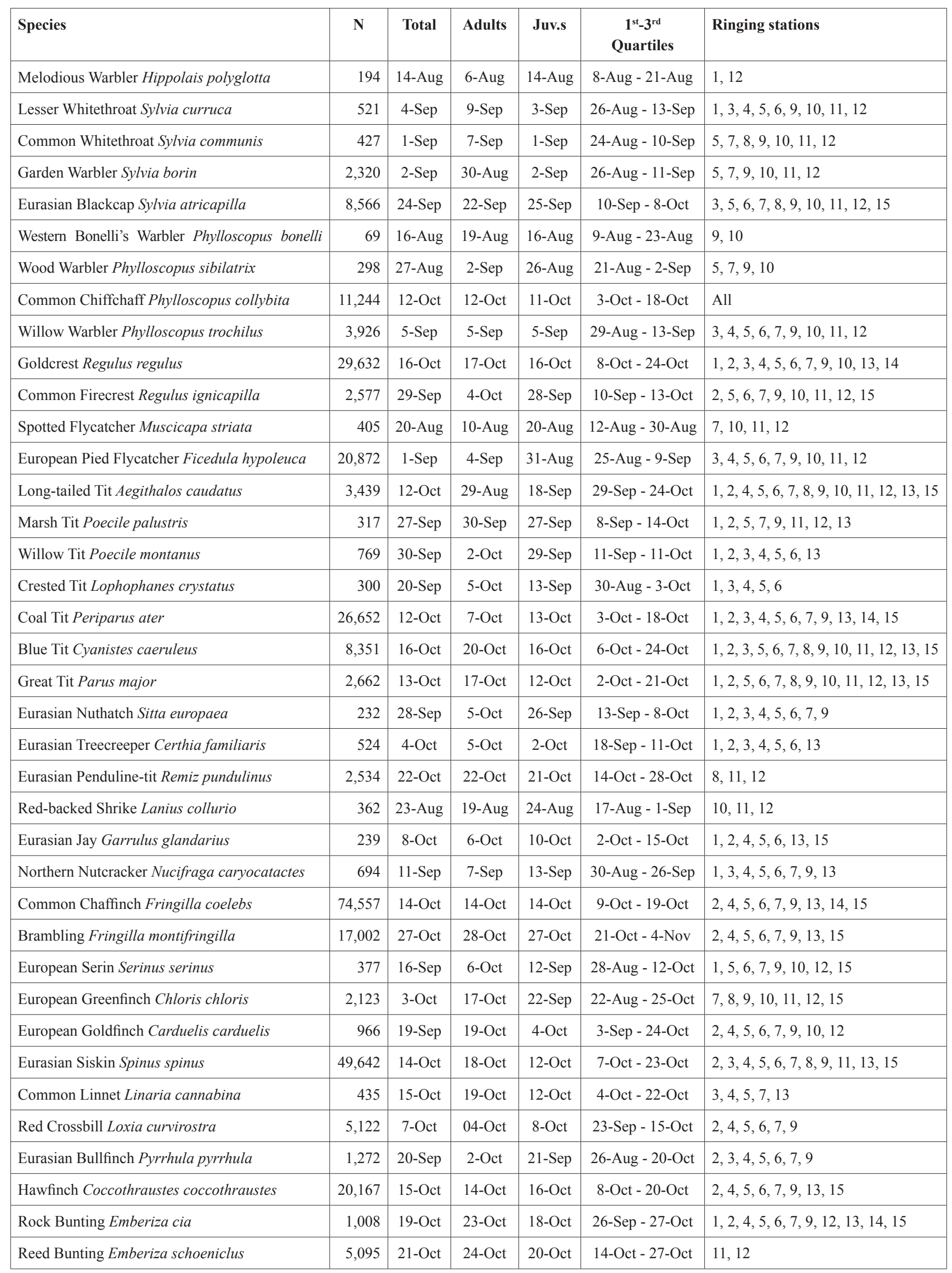


Tab. 5 - Inter-annual variation of phenology: list of species, number of individuals included in the analyses, best model selected, and ringing stations included in the analyses (see Tab. 1). Model MODP8 indicates variation in year-by-station average capture dates. / Variazione interannuale della fenologia: elenco delle specie, $\mathrm{N}$ inanellamenti inclusi nell'analisi, modello scelto e codice delle stazioni incluse nell'analisi (vedi Tab.1). Il modello MODP8 indica una variazione annuale e per stazione della data media stimata di cattura.

\begin{tabular}{|l|r|r|l|}
\hline Species & \multicolumn{1}{|c|}{ N } & Selected model & Ringing stations \\
\hline Tree Pipit Anthus trivialis & 521 & MODP8 & 5,10 \\
\hline Northern Wren Troglodytes troglodytes & 1,643 & MODP8 & $5,7,10,12$ \\
\hline Dunnock Prunella modularis & 2,366 & MODP8 & $4,5,10,12$ \\
\hline European Robin Erithacus rubecula & 34,413 & MODP8 & $4,5,7,9,10,12$ \\
\hline Black Redstart Phoenicurus ochruros & 1,000 & MODP8 & $4,5,7$ \\
\hline Common Redstart Phoenicurus phonicurus & 2,381 & MODP8 & $4,5,7,10,12$ \\
\hline Eurasian Blackbird Turdus merula & 1,917 & MODP8 & $4,5,9,10,12$ \\
\hline Song Thrush Turdus philomelos & 3,612 & MODP8 & $4,5,9,10$ \\
\hline Eurasian Blackcap Sylvia atricapilla & 5,139 & MODP8 & $9,10,12$ \\
\hline Garden Warbler Sylvia borin & 1,730 & MODP8 & 10,12 \\
\hline Common Chiffchaff Phylloscopus collybita & 7,927 & MODP8 & $5,7,9,10,12$ \\
\hline Willow Warbler Phylloscopus trochilus & 3,229 & MODP8 & $5,7,9,10,12$ \\
\hline Goldcrest Regulus regulus & 14,925 & MODP8 & $4,5,7,9,10$ \\
\hline Common Firecrest Regulus ignicapilla & 968 & MODP8 & 5,9 \\
\hline European Pied Flycatcher Ficedula hypoleuca & 17,445 & MODP8 & $5,7,9,10,12$ \\
\hline Eurasian Blue Tit Cyanistes caeruleus & 2,381 & MODP8 & $9,10,12$ \\
\hline Great Tit Parus major & 879 & MODP8 & $12,10,9$ \\
\hline Coal Tit Periparus ater & 12,940 & MODP8 & $4,5,9$ \\
\hline Common Chaffinch Fringilla coelebs & 51,170 & MODP8 & $4,5,7,9$ \\
\hline Brambling Fringilla montifringilla & 12,216 & MODP8 & $4,5,7,9$ \\
\hline Eurasian Siskin Spinus spinus & 38,708 & MODP8 & $4,5,7,9$ \\
\hline Red Crossbill Loxia curvirostra & 4,396 & MODP8 & $4,5,7,9$ \\
\hline Hawfinch Coccothraustes coccothraustes & 15,030 & MODP8 & $4,5,7,9$ \\
\hline
\end{tabular}

Tab. 6 - Inter-annual trend in the number of ringed birds: list of species, number of individuals included in the analyses, selected model (MODT1, MODT2, MODT3, MODT4), indication of whether a linear trend in abundance was supported (no trend, increase, decrease), trend slope (mean and standard error). / Andamento interannuale del numero di individui inanellati: lista delle specie, numero di inanellamenti inclusi nell'analisi, modello scelto (MODT1, MODT2, MODT3, MODT4), andamento rilevato dal modello (stabile, in aumento, in calo), pendenza dell'andamento (media ed errore standard).

\begin{tabular}{|l|r|c|c|c|c|}
\hline Species & \multicolumn{1}{|c|}{ N } & Selected model & Trend & Slope & Error \\
\hline Great Spotted Woodpecker Dendrocopos major & 185 & MODT3 & no trend & & \\
\hline Tree Pipit Anthus trivialis & 929 & MODT3 & no trend & & \\
\hline Meadow Pipit Anthus pratensis & 703 & MODT1 & no trend & & \\
\hline Water Pipit Anthus spinoletta & 633 & MODT1 & no trend & & \\
\hline Northern Wren Troglodytes troglodytes & 2,064 & MODT1 & no trend & & \\
\hline Dunnock Prunella modularis & 2,562 & MODT1 & no trend & & \\
\hline European Robin Erithacus rubecula & 34,413 & MODT3 & no trend & & \\
\hline
\end{tabular}




\begin{tabular}{|c|c|c|c|c|c|}
\hline Species & $\mathbf{N}$ & Selected model & Trend & Slope & Error \\
\hline Black Redstart Phoenicurus ochruros & 1,041 & MODT3 & no trend & & \\
\hline Common Redstart Phoenicurus phoenicurus & 2509 & MODT3 & no trend & & \\
\hline Whinchat Saxicola rubetra & 819 & MODT2 & Decrease & -0.37 & 0.08 \\
\hline Eurasian Blackbird Turdus merula & 2,027 & MODT2 & Increase & +0.37 & 0.07 \\
\hline Song Thrush Turdus philomelos & 3,954 & MODT2 & Increase & +0.39 & 0.10 \\
\hline Redwing Turdus iliacus & 227 & MODT1 & no trend & & \\
\hline Mistle Thrush Turdus viscivorus & 455 & MODT1 & no trend & & \\
\hline Cetti's Warbler Cettia cetti & 433 & MODT1 & no trend & & \\
\hline Common Reed-warbler Acrocephalus scirpaceus & 6,317 & MODT2 & Decrease & -0.13 & 0.05 \\
\hline Lesser Whitethroat Sylvia curruca & 365 & MODT1 & no trend & & \\
\hline Common Whitethroat Sylvia communis & 389 & MODT3 & no trend & & \\
\hline Garden Warbler Sylvia borin & 2,055 & MODT1 & no trend & & \\
\hline Eurasian Blackcap Sylvia atricapilla & 5,254 & MODT1 & no trend & & \\
\hline Common Chiffchaff Phylloscopus collybita & 8,072 & MODT1 & no trend & & \\
\hline Willow Warbler Phylloscopus trochilus & 3,451 & MODT2 & Decrease & -0.19 & 0.04 \\
\hline Goldcrest Regulus regulus & 14,993 & MODT1 & no trend & & \\
\hline Common Firecrest Regulus ignicapilla & 1,352 & MODT2 & Increase & +0.45 & 0.09 \\
\hline Spotted Flycatcher Muscicapa striata & 409 & MODT1 & no trend & & \\
\hline European Pied Flycatcher Ficedula hypoleuca & 18,446 & MODT3 & no trend & & \\
\hline Long-tailed Tit Aegithalos caudatus & 1,750 & MODT2 & Increase & +0.30 & 0.10 \\
\hline Coal Tit Periparus ater & 13,643 & MODT1 & no trend & & \\
\hline Eurasian Blue Tit Cyanistes caeruleus & 3,790 & MODT3 & no trend & & \\
\hline Great Tit Parus major & 1,238 & MODT3 & no trend & & \\
\hline Willow Tit Poecile montanus & 489 & MODT1 & no trend & & \\
\hline Eurasian Treecreeper Certhia familiaris & 396 & MODT3 & no trend & & \\
\hline Red-backed Shrike Lanius collurio & 363 & MODT4 & Decrease & -0.44 & 0.17 \\
\hline Common Chaffinch Fringilla coelebs & 51,165 & MODT1 & no trend & & \\
\hline Brambling Fringilla montifringilla & 12,226 & MODT1 & no trend & & \\
\hline European Serin Serinus serinus & 191 & MODT1 & no trend & & \\
\hline European Greenfinch Chloris chloris & 1,171 & MODT1 & no trend & & \\
\hline European Goldfinch Carduelis carduelis & 812 & MODT3 & no trend & & \\
\hline Eurasian Siskin Spinus spinus & 38,743 & MODT1 & no trend & & \\
\hline Common Linnet Linaria cannabina & 390 & MODT1 & no trend & & \\
\hline Red Crossbill Loxia curvirostra & 4,396 & MODT1 & no trend & & \\
\hline Eurasian Bullfinch Pyrrhula pyrrhula & 458 & MODT1 & no trend & & \\
\hline Hawfinch Coccothraustes coccothraustes & 15,335 & MODT1 & no trend & & \\
\hline Rock Bunting Emberiza cia & 410 & MODT3 & no trend & & \\
\hline Reed Bunting Emberiza schoeniclus & 4,726 & MODT3 & no trend & & \\
\hline
\end{tabular}




\section{Inter-annual trend of the ratio between the number of juveniles and adults ringed}

The yearly trend of the ratio between the number of juveniles and the number of adults ringed was tested for 18 species (Tab. 7). Among these, the Willow Warbler (ratio slope 1.48, std error 0.67) and the Reed Bunting (ratio slope 2.22, std error 0.58) showed a significant increase in the proportion of juveniles during the study period. In general, the number of juveniles is higher than that of adults in most of the species. There is a clear prevalence of juveniles in the Common Reed-warbler: it is possible that the majority of adults leave breeding grounds as early as July, a period not monitored by the stations of Progetto Alpi. The proportion of juveniles was lower in some species: in particular, Chaffinch, Brambling and Hawfinch often showed ratios with a prevalence of adults in some years. Finally, the ratio varied over the years for all species.

\section{DISCUSSION}

The standardized monitoring of late-summer and autumn migration across the Italian Alps carried out by several ringing stations has allowed to describe quite a complex phenomenon that is difficult to interpret in detail. It is evident that the crossing of the Alpine Chain takes place in very different ways among species. Firstly, the Progetto Alpi appears more suitable for monitoring passerine migration rather than the non-passerine component of migrants. The late summer migration of the trans-Saharans was detected at all altitudes, but the stop over seemed to occur mainly in the valley bottoms, in wetlands and open habitats. Some species were effectively more common than others (the most captured are the Common Redstart, the Willow Warbler and the Pied Flycatcher), and captured also at medium and high altitude. Species that remain mostly insectivorous (e.g., Pied Flycatcher) also in late summer during post-breeding migration seem not to avoid the stop over at higher elevations; contrariwise, there was a dominance of baccivorous species (e.g., Garden Warbler) and wetland species (e.g., Common Reedwarbler) in the valley bottom stations. Autumn migration, characterized mainly by the intra-Palaearctic migrants, shows a more abundant presence of birds at medium-high mountain, due to the massive presence of diurnal flockmigrants such as Finches and Tits. However, stopover of many species, such as Warblers and Chats, continues to occur mainly in the valley bottoms, underlining once more the importance of wetlands for migratory birds in the Alpine Region; contrariwise, several species, especially

Tab. 7 - Inter-annual trend of the ratio between the number of the juvenile and adults ringed: list of species, number of adults and juveniles included in the analyses, best model selected (MODR1, MODR2), mean age ratio and standard deviation of the selected model, result trend in the age ratios (no trend, increase, decrease). / Andamento interannuale del rapporto tra il numero di giovani e adulti inanellati: lista delle specie, numero totale di adulti e giovani inclusi nell'analisi, modello selezionato (MODR1, MODR2), rapporto giovani-adulti medio e deviazione standard del modello selezionato, andamento rilevato dal modello (stabile, in aumento, in calo).

\begin{tabular}{|l|r|r|r|r|l|l|}
\hline Species & N adults & $\begin{array}{c}\text { N } \\
\text { juveniles }\end{array}$ & $\begin{array}{c}\text { Selected } \\
\text { model }\end{array}$ & $\begin{array}{c}\text { Mean } \\
\text { ratio }\end{array}$ & SD & Trend \\
\hline Northern Wren Troglodytes troglodytes & 321 & 1,630 & MODR1 & 5.33 & 0.49 & no trend \\
\hline Dunnock Prunella modularis & 479 & 2,013 & MODR1 & 4.55 & 0.41 & no trend \\
\hline European Robin Erithacus rubecula & 5,506 & 28,789 & MODR1 & 5.84 & 0.30 & no trend \\
\hline Common Redstart Phoenicurus phoenicurus & 270 & 2,213 & MODR1 & 9.02 & 0.89 & no trend \\
\hline Eurasian Blackbird Turdus merula & 607 & 1,414 & MODR1 & 2.87 & 0.31 & no trend \\
\hline Song Thrush Turdus philomelos & 534 & 3,387 & MODR1 & 8.04 & 0.96 & no trend \\
\hline Common Reed-warbler Acrocephalus scirpaceus & 318 & 5,993 & MODR1 & 20.45 & 1.84 & no trend \\
\hline Eurasian Blackcap Sylvia atricapilla & 675 & 4,484 & MODR1 & 7.50 & 0.63 & no trend \\
\hline Common Chiffchaff Phylloscopus collybita & 1,171 & 6,284 & MODR1 & 6.32 & 0.76 & no trend \\
\hline Willow Warbler Phylloscopus trochilus & 382 & 2,657 & MODR2 & 7.94 & 0.68 & increase \\
\hline Goldcrest Regulus regulus & 1,171 & 6,284 & MODR1 & 6.75 & 0.49 & no trend \\
\hline European Pied Flycatcher Ficedula hypoleuca & 2,974 & 15,392 & MODR1 & 5.58 & 0.40 & no trend \\
\hline Common Chaffinch Fringilla coelebs & 23,025 & 27,498 & MODR1 & 1.24 & 0.11 & no trend \\
\hline Brambling Fringilla montifringilla & 5,568 & 6,377 & MODR1 & 1.17 & 0.13 & no trend \\
\hline European Greenfinch Chloris chloris & 315 & 809 & MODR1 & 2.83 & 0.33 & no trend \\
\hline Eurasian Siskin Spinus spinus & 12,402 & 26,118 & MODR1 & 2.12 & 0.32 & no trend \\
\hline Hawfinch Coccothraustes coccothraustes & 9,069 & 5,185 & MODR1 & 0.60 & 0.05 & no trend \\
\hline Reed Bunting Emberiza schoeniclus & 994 & 3,596 & MODR2 & 5.83 & 0.67 & increase \\
\hline
\end{tabular}


those that becomes granivorous in non-breeding season, may stopover also high up in the mountains, suggesting that the Alpine chain might be suitable as a migratory corridor for them. The phenology of captures of the different species highlighted once more the migratory strategies of the different species, and suggested the timing of dispersal for the resident species. Those trans-Saharans and intra-Palaearctics abundantly ringed at medium and higher altitudes should be referred as the effective followers of the Italian-Hispanic migratory route (Duse, 1930), and Italian Alps as one of their flyway to the wintering grounds. Species that were rarely captured in the mountain passes, ridges and slopes in the Italian Alps, but abundantly in the valley bottoms, could be those for which the Alpine Chain represents an ecological barrier.

We did not observe temporal trends in mean date of passage for the species we analyzed, but the analyses highlighted differences between stations at different elevation and variation in the estimated dates among the years. This scenario may suggest that meteorological conditions (rainy fronts, winds) can affect considerably the captures in the whole Alpine Italian Region (Haest et al., 2019). Future research should deepen and investigate these aspects. Contrary to our results, an analysis in the Swiss Alps highlighted a delay in the average date of passage for some intra-Palearctic migrants and an anticipation of the date for some trans-Saharan migrants (Jenni \& Kéry, 2003). Changes in date of passage observed for several species in the Western Alps appeared not to occur in the Italian Alps. However, Jenni and Kéry treated a much more longer time-lapse that included almost 40 years of ringings between the $50 \mathrm{~s}$ and the 90 s of the last century, while our work regards only the first two decades of the new Millennium.

As regards the trend of captures, we have recorded an increase in ringings of four species and the decrease of another four. The trend in abundance of migratory birds could be related to the trends of their breeding populations. Indeed, species showing a negative trend (Whinchat, Common Reed-warbler, Willow Warbler, Red-backed Shrike) are also having dramatic decreases in their population trends in the last 40 years, due to habitat loss and climate change (Bowler et al., 2019; Gregory et al., 2019). Forest species, such as Blackbird, Song Thrush, Firecrest and Long-tailed Tit (all showing a significant increase in captures) show a stable trend since the 1980s (Gregory et al., 2019), and our results may concern about singular geographical populations that might have enlarged their geographical distributions in the last decades.

Changes in the ratio between juveniles and adults occurred in two species (Willow Warbler and Reed Bunting), showing an increase in the proportion of juveniles during the study period. This shift to a higher proportion of juveniles could be related to aspects of age-dependent en route behavior and ecology, related also to environmental variables at wider geospatial scale than Alps (Woodrey, 2000). Further investigations are needed to explore intra-specific correlations in the proportion between juveniles and adults ringed and total abundance of migrants.
All the analyses tried to investigate some aspects that where aims of the Project since its birth. However, the results we presented may contain a fair amount of biases, due mainly to the sampling system. The nature of the studied system and the used sampling design do not make the detection probability of individuals uniform in the different sites (capture station) and in the time unit (day). These inhomogeneities prevented us from calculating the probability of contacting individuals (Kéry \& Schaub, 2012) and therefore from being able to estimate the portion of migrants that actually passed through each ringing station every day (and therefore potentially catchable). Confounding effects as seasonal variations in local environmental conditions (e.g., changes in the habitats surrounding the mist-nets, due to fires, cuts in vegetation, flooding of water bodies) and meteorology at different geographical scales (from local-alpine to regional-alpine or continental; e.g., wind, fog, rain fronts), as well as the biological, physiological and physical characteristics of the single species and individuals (e.g., flight modes, fat conditions), considerably affected the detection probability and influence the catchability of the birds. For this reason, it was not possible to consider the number of birds captured as a valid index of the number of migratory birds actually transiting in the ringing stations. Various approaches could therefore be employed, both to read and interpret the observed data, and to use an analytical approach within, for example, both a frequentist and a Bayesian framework, each with different advantages and disadvantages (e.g., Jenni \& Kéry, 2003; Zuur et al., 2009; Kéry \& Schaub, 2012; Lindén et al., 2017). In the present work we tried to illustrate and analyze the data in the most objective and uniform possible approach, using analytical methods that treated the quantities of main interest directly as a response variable, and therefore more easily interpretable.

For more in-depth interpretation of these analyses different approaches are needed. The origin of migrants is unknown and limits the interpretation of the estimated models. The area of origin of most of the species lies between the Alps, the Baltic Basin and the Eastern Europe until the Urals (Jenni \& Kéry, 2003; Spina \& Volponi, 2008, 2009; Franzoi, 2016; Franzoi et al., 2020). Knowledge of the different geographic source areas of at least the common regular migrants, obtained using intrinsic or extrinsic markers (Hobson \& Norris, 2018), of the Italian-Hispanic route could be used in comparing population trend estimates from breeding censuses and ringing data (Dunn et al., 1997; Maggini et al., 2021). Further investigations are needed to understand the phenomenon of post-breeding migration through Italian Alps, including deepening in physiology and ecology of birds, climatic and meteorological effects, improvement of monitoring techniques. Detailed analyses and figures of each of the 69 species mentioned in this manuscript are reported and discussed in Pedrini et al. 2021.

\section{Acknowledgements}

We are very grateful to A. von Hardenberg, and another anonymous reviewer which provided very construc- 
tive comments that helped and stilted us to improve a first draft of our manuscript. We also thank all the many people involved in the ringing activity and the financial support of numerous public and private Institutions that have been determining the success of the Progetto Alpi among the years. The Progetto Alpi and this publication have been supported by MUSE, Autonomous Province of Trento.

\section{REFERENCES}

Akaike H., 1973 - Information theory as an extension of the maximum likelihood principle. In: Second International Symposium on Information Theory. B. N. Petrov \& F. Csaki (eds.). Akademiai Kiado, Budapest, Hungary: 267-281.

Arnold T. W., 2010 - Uninformative parameters and model selection using Akaike's Information Criterion. The Journal of Wildlife Management, 74 (6): 11751178.

Aschwanden J., Schmidt M., Wichmann G., Stark H., Peter D., Steuri T. \& Liechti F., 2019 - Barrier effects of mountain ranges for broad-front bird migration. Journal of Ornithology: <https://doi.org/10.1007/s10336019-01704-4>

Bates D., Maechler M., Bolker B. \& Walker S., 2015 - Fitting Linear Mixed-Effects Models Using lme4. Journal of Statistical Software, 67 (1): 1-48. < doi:10.18637/ jss.v067.i01>

Bowler D. E., Heldbjerg H., Fox A. D., de Jong M. \& Böhning-Gaese K., 2019 - Long-term declines of European insectivorous bird populations and potential causes. Conservation Biology, 33 (5): 1120-1130. <https://doi.org/10.1111/cobi.13307>

Bruderer B., 1996 - Vogelzugforschung im Bereich der Alpen 1980-1995. Ornithologische Beobachter, 93: 119-130.

Bruderer B. \& Jenni L., 1990 - Migration across the Alps. In: Bird migration: Physiology and ecophysiology. Gwinner E. (ed.), Springer-Verlag, Berlin: 60-77.

Bruderer B. \& Winkler R., 1976 - Vogelzug in den Schweizer Alpen. Angewandte Ornithologie, 5 (1): 32-54.

Dunn E. H., Hussell D. J. T. \& Adams R. J., 1997 - Monitoring Songbird Population Change with Autumn Mist Netting. The Journal of Wildlife Management, 61 (2): 389-396.

Dunn E. H., Hobson K. A., Wassenaar L. I., Hussell D. J. T. \& Allen M. L., 2006 - Identification of Summer Origins of Songbirds Migrating through Southern Canada in Autumn. Avian Conservation and Ecology, 1 (2): 4. < http://www.ace-eco.org/voll/iss2/art4/>

Duse A., 1930 - L'Osservatorio ornitologico del Garda. Bollettino di Zoologia, 1 (1): 13-16.

EURING (The European Union for Bird Ringing), 2020 The EURING Exchange Code 2020. Helsinki, Finland.

Gregory R. D., Skorpilova J., Vorisek P. \& Butler S., 2019 - An analysis of trends, uncertainty and species selection shows contrasting trends of widespread forest and farmland birds in Europe. Ecological Indicators, 103: 676-687. <https:// doi.org/10.1016/j. ecolind.2019.04.064>
Franzoi A., 2016 - Animal Ecology through Stable Isotopes Analyses. PhD Thesis, Università degli Studi di Pavia.

Franzoi A., Bontempo L., Kardynal K. J., Camin F., Pedrini P. \& Hobson K. A., 2020 - Natal origins and timing of migration of two passerine species through the southern Alps: inferences from multiple stable isotopes $\left(\delta^{2} \mathrm{H}, \delta^{13} \mathrm{C}, \delta^{15} \mathrm{~N}, \delta^{34} \mathrm{~S}\right)$ and ringing data. Ibis, 162 (2): 293-306. < https://doi: 10.1111/ibi.12717>

Haest B., Hüppop O., van de Pol M. \& Bairlein F., 2019 - Autumn bird migration phenology: A potpourri of wind, precipitation and temperature effects. Glob Change Biology, 25: 4064-4080. <https://doi. org: $10.1111 / \mathrm{gcb} .14746>$

Hobson K. A. \& Norris D. R., 2018 - Animal migration: a context for using new techniques and approaches. In: Tracking animal migration with stable isotopes. Hobson K. A. \& Wassenaar L. I., (eds.). Elsevier: $1-20$.

Jenni L. \& Kéry M., 2003 - Timing of autumn bird migration under climate change: advances in long-distance migrants, delays in short-distance migrants. Proceedings of the Royal Society of London, Series B: Biological Sciences, 270 (1523): 1467-1471.

Kéry M., 2010 - Introduction to WinBUGS for ecologists: Bayesian approach to regression, ANOVA, mixed models and related analyses. Academic Press.

Kéry M. \& Schaub M., 2012 - Bayesian population analysis using WinBUGS: a hierarchical perspective. $\mathrm{Aca}$ demic Press.

Liechti F., Bruderer B. \& Paproth H., 1995 - Quantification of Nocturnal Bird Migration by Moonwatching: Comparison with Radar and Infrared Observations. Journal of Field Ornithology, 66 (4): 457-468.

Liechti F., Dieter P., Lardelli R. \& Bruderer B., 1996 Herbstliecher Vogelzug im Alpenraum nach Monbedaschtugen. Topographie und Wind beeinflussen den Zugverlauf. Ornithologische Beobachter, 93: 131152.

Lindén A., Meller K. \& Knape J., 2017 - An empirical comparison of models for the phenology of bird migration. Journal of Avian Biology, 48 (2): 255-265.

Maggini I., Cardinale M., Favaretto A., Voříšek P., Spina F., Maoret F., Ferri A., Riello S. \& Fusani L., 2021 - Comparing population trend estimates of migratory birds from breeding censuses and capture data at a spring migration bottleneck. Ecology and Evoution, 11 (2): 967-977. <https://doi.org/10.1002/ ece3.7110>

McCullagh P. \& Nelder J. A., 2019 - Generalized linear models. Routledge.

Micheli A. \& Pedrini P., 2000 - Prime ipotesi sulle rotte migratorie autunnali degli Uccelli in Trentino. Studi Trentini di Scienze Naturali, Acta Biologica, 74 (1997): 143-154.

Pedrini P. \& Spina F., 2021 - Un po' di storia del Progetto ALPI. Rivista Italiana di Ornitologia, 91 (2): 3-10.

Pedrini P., Spina F., Negra O., Rizzolli F., Pallaveri A. \& Rossi F., 2003 - Il Progetto Alpi. Rivista Italiana di Ornitologia, 72 (2): 185-194. 
Pedrini P., Rossi F., Rizzolli F. \& Spina F., 2008 - Le Alpi italiane quale barriera ecologica nel corso della migrazione post-riproduttiva attraverso l'Europa. Risultati generali della prima fase del Progetto Alpi (1997-2002). Biologia e Conservazione della Fauna, 116: $1-336$.

Pedrini P., Tenan S. \& Spina F. (a cura di), 2012 - La migrazione postriproduttiva degli Uccelli attraverso le Alpi italiane: fenologia ed andamenti. Museo delle Scienze.

Pedrini P., Franzoi A., Lorenzo Sanchez P., Rossi F., Tenan S., Spina F., Tenan S., Rossi F., Bandini M., Calvi G., Colnago F., Corno G., Noselli S., Schiavi M., Vitulano S., Accantelli D., Barbarino F., Bertoli R., Borgo E., Dendena R., Fasano S., Favaretto A., A. Galimberti, Leo R., Nicastro M., Pavia M., Prugger I., Rosselli D., Tamietti A., Viganò E., Serra L., 2021 - Le specie in transito, fenologie e loro andamenti. Rivista Italiana di Ornitologia, 91 (2): 29-144.

Pinheiro J., Bates D., DebRoy S., Sarkar D., R Core Team, 2020 - nlme: Linear and Nonlinear Mixed Effects Models. R package version 3.1-148. <https:// CRAN.R-project.org/package $=$ nlme $>$

R Development Core Team, 2010 - R: A Language and Environment for Statistical Computing. R Foundation for Statistical Computing, Vienna, Austria. <http:// www.R-project.org/>

Rössler M. \& Schauer C., 2014 - Flugrichtungen und räumliche Verteilung des nächtlichen Vogelzuges über den Ostalpen: Mondbeobachtungen 2005-2007. Ornithologische Beobachter, 111: 173-186.

Spina F. \& Volponi S., 2008 - Atlante della migrazione degli Uccelli in Italia. 1. non-Passeriformi. Ministero dell'Ambiente e della Tutela del Territorio e del Mare, Istituto Superiore per la Protezione e la Ricerca Ambientale (ISPRA). Tipografia SCR, Roma.

Spina F. \& Volponi S., 2009 - Atlante della migrazione degli Uccelli in Italia. 2. Passeriformi. Ministero dell'Ambiente e della Tutela del Territorio e del Mare, Istituto Superiore per la Protezione e la Ricerca Ambientale (ISPRA). Tipografia SCR, Roma.

Venables W. N. \& Ripley B. D., 2002 - Modern Applied Statistics with S, Fourth edition. Springer, New York. $<$ http://www.stats.ox.ac.uk/pub/MASS4>

Woodrey M. S., 2000 - Age-dependent aspects of stopover biology of passerine migrants. Studies in Avian Biology, 20: 43-52.

Zuur A. F., Ieno E. N., Walker N. J., Saveliev A. A. \& Smith G. M., 2009 - Mixed effects models and extensions in ecology with R. Springer, New York.

\section{SUPPORTING INFORMATION}

Additional Supporting Information may be found online for this article.

SI1 - Intensity and duration of sampling in the 15 analyzed stations. / Intensità e durata del campionamento nelle 15 stazioni analizzate.

SI2 - Results of the model selection for the inter-annual variation in phenology of 23 species (degree of freedom, AIC estimator, log-likelihood). / Risultati della selezione dei modelli che testano la variazione annuale della fenologia per 23 specie.

SI3 - Results of the model selection for the inter-annual trend of the number of birds ringed of 45 species (degree of freedom, AIC estimator, log-likelihood). / Risultati della selezione dei modelli che testano l'andamento annuale del numero di uccelli inanellati per 45 specie. 